\title{
Independency of Bank Guarantee in Iran -US Claims Tribunal: Looking for Legal Approach for Minimizing the Risk of Economic Contracts
}

\author{
Mohammad Sadeghi ${ }^{\mathrm{a}}$ \\ Ali Ahamdi ${ }^{\text {b }}$ \\ ${ }^{a}$ Hormoz Research Center, University of Hormozghan, Iran \\ ${ }^{b}$ Researcher in International Law
}

mohammad.sadeghi@hormozghan.ac.ir

Submission date:- 7/3/2018 Acceptance date:- 4/4/2018 Publication date:- 14/10/2018

Keywords: Bank Guarantees, Independency of Guarantees, Iran-US Claims Tribunal.

\begin{abstract}
Bank guarantees are significant instrument in business contracts, especially in minimizing the risk of economic contracts in light of international contracts. Furthermore, the bank guarantee has positive impact on legal reliability International contracts among the parties. In line with that the independency of bank guarantee from contract terms is other advantage that has been led to consider the bank guarantee as an innovative financial instrument to increase the chance of minimizing the risks. The fact is that bank guarantee associated with paying amount of guarantee in cash and gets rid of the legal dispute over the formalities and delays in getting the right when one party of the contract did not fulfill its obligations. This potential capability of bank guarantee is still suffering lack of certainty on independency of bank guarantee in banking regulations. In this regard, the judgment of international arbitration and their procedures are valuable in understanding and analyzing the banking regulation about bank guarantees. The judgments of international arbitration mostly consider as one appropriate source to manifest a proper approach for legal analysis of independency. Thus, this research would review Iran US Claims Tribunal as one of the significant cases to find out whether the tribunal has been able to eliminate the legal ambiguities and promote the legal position of these tools through such judgments?
\end{abstract}

\section{1- Introduction}

In international trade, careful evaluation of potency and technical and financial ability of the parties of a contract who have no knowledge about each other, often is not so simple. It is also possible during doing this or after the contract events occur by which the parties fail to fulfill their obligations, intentionally or unintentionally. So, existence of a safe guarantee for implementation of the contract seems necessary, the employer or the buyer therefore can ask required guarantee from the other party to ensure from the power and ability of the contractor or vendor who is the other party of the contract.

The purpose of the guarantee is to secure guarantee for the obligate that has been in the contract and its subject is the irrevocable commitment a bank to pay the guaranteed amount in the event of non-fulfillment of the contract by the seller or guarantor to carrying out the contract. The guarantee is usually a separate obligation that is independent of the original debt and the base contract between the original creditor and the debtor. Under the terms of the guarantees, the bank must pay the amount of the guarantee to the principal with the first request, provided that the terms of the guarantee are adhered. 
The most fundamental principle governing bank guarantee is "the principle of independence of the bank guarantee from the base contract". The concept of the principle of independence of the guarantee is its independency from the base contract which led to the issuance of the guarantees, and the bank cannot contribute to the defense and objections arising from the base contract, as a result issues such as infringement or non-infringement of the principal (contractor) from the obligations of the base contract as well as the eligibility or non-eligibility of the beneficiary (employer) to demand compensation has no relevance to the relationship between the bank and the beneficiary. Therefore, in case of the fulfillment of terms and conditions of guarantees, the beneficiary is entitled to demand its amount and it is not required to prove the infringement in ways other than is specified in the guarantees.

There is an exception to the rule of the original guarantee being totally independent of the main contract, called "the fraud rule". According to this rule, only through fraudulent means can the principle of independence be ignored and payment of relevant amounts prevented. In case the request for payment under the bank guarantee can be associated with fraud or manifest abuse, then the guarantee seeker can - through immediate legal proceedings - obtain an injunction against the guarantor bank as well as the beneficiary and thus stop the payment.

All advantages of bank guarantees are still potential advantages rather than pragmatic advantages because of possibility of divergent interpretation on independency of bank guarantees. Therefore, case law is one of instrument to increase the chance of reaching appropriate interpretation on independency terms. Among the cases, (Iran-US Claims Tribunal) is one of relative and significant cases, which show the adequacy, and inadequacy of case law in term of assisting contractor to benefit from advantages of independency of bank guarantee.

The Islamic Revolution in Iran caused a crisis in commercial and financial relations with European countries, especially with USA. Differences in the contracts of buying and selling the goods and services raised many legal debates about the bank guarantees. The government of Iran and the government of USA for resolving their differences through the mediation of Algeria on 19 January 1981 signed Algeria Declarations.

These statements are aimed at resolving the case of the former embassy staffs of USA in Tehran and financial and legal disputes between the two countries, was issued as a result of the overthrow of Pahlavi regime because of Islamic Revolution and the establishment of the Islamic Republic in Iran. Among the issues that were the disputation of the two parties and also are mentioned explicitly in the declarations, are documental credits and bank guarantee that reviews and analyzes of the opinions of this tribunal, forms the subject of this article.

The issues is still open to debate, because still there is question that whether the tribunal (Iran-US Claims Tribunal) has been able to eliminate the legal ambiguities and promote the legal position of these tools through such judgments? In this regards this research will examine the principle of independence of the bank guarantee and other perspective as following in order to conclude the question with appropriate proposal.

\section{2- The Principle of Independence of the Bank Guarantee}

The concept of the principle of independence means that the guarantor (Bank) has assumed new commitments and the contract between the guarantee and the guarantor is a separate contract that is independent of the base contract. Upon the request of the beneficiary guarantee or as specified in the guarantee contract, the guarantor is committed to pay the amount of the guarantee. A practical result is obtained from this principle and it is the principle of lack of considering objections. Under this principle, the guarantor cannot cite against the beneficiaries, not the invalidity of the main contract nor to dissolve or terminate it, not permitted to the implementation that makes the guarantee, permitting [1] .

Uniform rules of International Chamber of Commerce for demand guarantees and the United Nations Convention for independence guarantees and expected credentials based on the current practice of International Chamber of Commerce, has accepted independency of reciprocal guarantee. Paragraph B of Article 2 of uniform regulation of the International Chamber of Commerce states that "Guarantees naturally based on contracts or conditions of the tender under which they are issued, are considered a separate transaction, and the guarantor despite referring to the contract or tender conditions on guarantee, do not deal with this contract and tender conditions at all, and it is not obliged to implement it" [2]. 
In paragraph A of Article 5 of URDG2010 also explicitly accepted such a principle and explicitly noted that guarantee is independent from the base relationship and the asking guarantee issuing and the base relationship has nothing to do with the guarantor and the guarantor is not obliged to it. Similar with that the UN Convention in Article 3 has described and defined of the independence of the guarantee that guarantee not depends on the existence and validity of any base contract or any other commitment. Moreover, it is not also subject to any tem and conditions "conditions that do not exist in the appearance of the document or any other possible incident or act other than the submission of documents, as well as acts or events that is within the scope of the guarantor [3].

As well as international regulation of guaranteeing letters of ISP98 that is guaranteed about the letters of credit explicitly decrees the rule of such a principle in Article 6.1 on the letters of credit, this article states that: "When a guarantee is issued, it is known as an irrevocable, independent, and binding commitment and there is no need to mention it in the guarantee"[4].

Over all it seems that the principle of independency of bank guarantee shows that its independency in whole filed exist and has been protected internationally. In this regards it need to mention that as has been briefly in the above part highlighted principle of the independency of bank guarantee has many effects. Therefore, these effects will be explained with all types of bank guarantee owing to their relation with the research question and aims.

\section{2-1- the Independency of Bank Guarantee from the Based Contract}

The first and most common effect that comes to mind is the independency of Bank guarantees from the base contract [5].The commitment of bank to pay the guarantee and the right of beneficiary to receive it, is determined according to the terms and contents of the guarantees, not the contract. Objections arising from the base and original contract cannot be a hindrance to pay the amount of the guarantees, and neither the bank nor the guarantor would not be able to use it as a tool to pay not the amount of the guarantees [1].

\section{2-2- should Bank Guarantee Be Considered as a Document}

If a condition has been determined to demand the amount of the guarantee, this condition should not be more than offering a document. This document can be in terms of agreement of the written notice of violation or the testimony of third party, referee decision or any other document that the parties have provided it in the context of guarantees [6]. In this part, the issue, which some time imposes some challenges on the reliability and no reliability of bank guarantee is the relationship and independency of such document. It would be analyzed in next part.

\section{2-3- the Independency of the Guarantee from the Relationship of the Bank with Guarantor}

Other effect of the independency of the bank guarantee is being separateness of the contract between the requesting the issuance of the guarantee (directive) and the guarantor bank. The commitment of the bank to pay is not affected by the obligations and the provisions stipulated in the contract between the guarantor and the bank and it will not be influenced by it, therefore the bank cannot bank rely on the defense that can be used against the guarantor[1] According to this principle, relations between the applicant of the issuance of the document and the bank and conditions stipulated in the contract between the two, is not related to the guarantee and the commitment of the bank to pay the guarantee is only based on the terms and provisions contained in the document of the guarantee, not the contract that is formed between the directive and the bank [5].

\section{2-4- Shifting the Burden of Proof of Claim from the Beneficiary to the Guarantor}

The mere existence of an independent guarantee in the hand of the beneficiary, in spite of the dispute with the other party of the contract (requesting the issuance of the document) or even denying him/her against the alleged infringement, gives him/her the right to collect the amount of the guarantee and when the requesting issuance prove that the beneficiary is not entitled to receive the guarantees, in the case of its proof in front of a competent authorities by him, there is the possibility of refund the collected guarantee by the beneficiary [7]. This represents a shift of the burden of claim proof from the independent beneficiary of the guarantee to the requesting of its issuance that is the most important effect of the independency of the bank guarantees. 


\section{3- Bank Guarantees in the Financial, Economic, and Banking Cases of Iran in Iran--U.S. Claims Tribunal}

Among the topics that were investigated in Iran-U.S. Claims Tribunal, were claims related to bank guarantees and letters of credit. In this section, we first investigate the tribunal's jurisdiction claims in the case of bank guarantee that is disputed between the parties, that each of them persisted on separate jurisdiction for the tribunal. And then judgments of tribunal in contractual claims of bank guarantee that have been ruled in the context of contractual demands and calculations will be investigated.

because of failing of US banks in the payment of letters of credit to Iranian banks, the central bank on behalf of Iranian banks claimed some demands in the tribunal: Central Bank claims that the executive order No. 12294 issued on February 24, 1981 which was replaced by Executive Order No. 12170, as well as Treasury regulations, reversal of General Declarations, in particular the general principle of "A", whereby, the United States promised to restore the financial situation of Iran to the status before November 14, 1979 as much as possible and ensure the movement of all Iranian assets within their territory freely. This executive order had been exempted the investigations related to credit or payment of letter of credit from this rule. The central bank had asked the tribunal to rule about each case and forced the United States Government and the American bank to pay the amount of letters of credit and compensate the damages to the Iranian parties as a result of non-payment of funds of letters of credits [8].

Furthermore, the central bank pointed to paragraph 17 of the General Declaration and wants from the tribunal to proof its jurisdiction to deal with all claims of Iranian banks related to letters of credit issued by USA Banks and US financial institutions[9], the central bank believes that the arbitral tribunal pursuant to paragraph 2 of Commitments Document[10] has the authority to investigate all such claims [11].

USA government believed that bank guarantees are outside the jurisdiction of the tribunal and believed thatOnly in accordance with paragraph 1 of Article 2 of the Claims Settlement Declaration the arbitral tribunal to investigate claims of Iranian banks based on letters of credit has the authority if it is raised in the mutual claims. And requested the arbitral tribunal to interpret the Declarations and Commitment Documents, whether the arbitral tribunal has the authority to investigate the banking claims about bank counter guarantees of US banking according to the Claims Settlement Declarations and Commitment Document or not? The same request was formed the topic of the case "16 A". The tribunal investigating the issue stated its decision in this way:

According to the decision dated on 21 January 1982 in the case of "A / 2" on lack of jurisdiction in cases brought directly by Iran against citizens of the United States, commented to the extent that claims of letters of credit of Iran banks against US banks based on the Claims Settlement Declaration, the tribunal has no jurisdiction to deal with such cases. There is no condition in the Claims Settlement Declaration, whereby, the tribunal jurisdiction over the parties independent of the government, such as a private bank, simply because that have common responsibility with a party which is subject to the tribunal's jurisdiction is extended. Also, to the extent that such claims brought by alleged in clause 2 "A" of article II Commitment Document is based on, according to the dispute issues of the parties for letters of credit is out of definition of claims referable to the tribunal in that paragraph. Therefore, the tribunal lacks jurisdiction to investigate it [1].

The Tribunal believes that the only explicit reference in the Algeria Declarations to the claims regarding the discretionary letters of credit appears in Clause 1, Article 2 of the Claims Settlement Declarations. The particular reference in the Claims Settlement Declarations states that the parties would like the claims regarding discretionary letters of credit to be resolved in accordance with the Claims Settlement Declarations rather than clause 2 of the Commitments Document. Therefore, the Tribunal cannot be allowed a more extensive jurisdiction than that specifically predicted for it in the Agreement [1]. According to Clause 2 of the Commitments Document, the Tribunal lacks the required jurisdiction to hear the claims brought by Iranian banks against American banks or American citizens [1].

As it was observed, the arbitral tribunal in the decision adopted in this case, to address the claims on behalf of Iranian banks against banks and companies of USA set up to demand the payment of the amount of the guarantee did not qualified itself and with this decision, about 230 Iranian claims for demand the payment of the amount of the guarantees which had been recorded in the tribunal, were failed. But the way which suggested by USA and the arbitral tribunal also did not deny it, but also assigned to the decision of each of the branches to investigate the cases, was that Iranian banks in the claims of foreign companies which are raised regarding the base and original contract, could ask their claims in the counterclaims [1].

The tribunal in these cases pays attention to the principle of independency of bank guarantee and has rejected the guarantee which Iranian party has demanded it in the counterclaim because of incapacity as would be explained in following parts. 


\section{3-1- Independency of the Guarantee from the Original Contract}

Claims which are considered as the principle of the independency of the guarantee from the original contract could be proved by the case of Haraz Engineering Company, Melli Bank of Iran and Tejarat Bank. In the case of Haraz Engineering Company, complainant demanded its account balances with Melli Bank of Iran and Tejarat Bank that these banks have refused to pay issued check. Tejarat Bank besides rejected the plaintiff's claim, raised mutual claims that its topic was the demand for bank guarantees [12].

Original claim of the complainant was rejected, but concerning the counterclaim related to the guarantees, the second branch of the arbitral tribunal commented is that:" Bank guarantee is a financial document and guarantee the commitments that are the original transaction contract which guarantee is one of its provisions and, is independent and distinct" [13].

Furthermore, In the case of the claim of International Technical Products[14]that Tejarat Bank according to the counterclaim against the US Company, demanded the payment of the amounts of guarantees, the tribunal has been disclaimed the counterclaims regarding the independency of the original contract and also the lack of the capacity of bank [7].

\section{3-2- Ignoring the Independency of the Guarantee from the Original Contract}

As we shall see in the following examples of tribunal decisions, both Plaintiffs and the tribunal have tried to resolve the guarantee in the framework of demands and contractual calculations or terminate the contract and so on. And so, the tribunal has completely abandoned the issue of the independency of the guarantee from the base contract. It will be analyzed and review through the following cases;

\section{3-2-1 Eastman Kodak Company Case}

On January 12, 1982, Eastman Kodak Company has recorded a lawsuit against the government of the Islamic Republic of Iran, photography services Company of Rangiran, Meli Bank, Sepah Bank, Iran and England Bank and the Central Bank of Iran. This claim was registered under the case number 227 [15]. Eastman Kodak demanded to cancel the guarantees, which it had done to guarantee the works. As a brief, Tejarat Bank rejected the demanded claims; because of this the guarantees are valid and enforceable without doubt and because the original obligations are unpaid, have demanded the guarantees. Thus, the plaintiff, Eastman Kodak Company was not liable for any contingent arising from the guarantees issued on March 19, 1979, in favor of Iran and Britain Bank, which is now defendant, Tejarat Bank, is its successor and the defendant, Tejarat Bank is committed to refund any demand from Eastman Kodak for this guarantees. Similar with that can find in the case Sylvania Technical Systems Incorporated [16].

\section{3-2-2 Sylvania Technical Systems Incorporated}

The present case is contained a claim of breach of the contract that is for training Air Force personnel of Iran, Sylvania alleges that the defendant (the government of Islamic Republic of Iran) in January and February 1979 violated the contract. The Iranian government claims that the plaintiff nullified or canceled the contract.

Another claim that the plaintiff have asked is that the bank guarantees and letters of credit pursuant to the contract, which are deposited as a guarantee for good performance of the work and for prepayment of the plaintiff, be free and terminated [16].

The defendant additionally requested to ask from the plaintiff to cancel the detention contracts from US courts and prevent the receipt of letters of credit related to guarantee good performance of the work of plaintiff and prepayments of defendant. The defendant argues that the contract allowed him that in case of its violation by the plaintiff, demand the payment of letter of credit [9].

The tribunal believes that Iranian government based on a deliberate policy, would not continue the contracts with US contractors and has caused to cancel it. The guarantees issued by the Iranshahr Bank are expired and hereby it is ordered to the defendant that refund all the requests related to the above guarantees and refrain from claiming it [17].

\section{4- Discussion and Conclusion}

This study, based on the reviewing and analyzing the aforementioned cases come to this conclusion that, arbitral tribunal procedures on bank guarantees is uncoordinated and discontinuous. The tribunal views to the principle of independency of the guarantees, which is an accepted principle by the customs and norms of international law. It seems criticism and protest 
because the principle of the independency of guarantees from the original and base contract is ignored and the status of a bank guarantees, in a counterclaim with the issue of the main contract is ruled. And, unfortunately the tribunal did not any effort to appreciate the principle of the independency in their judgments.

The Tribunal has, in the past, issued different votes for greatly similar cases - such as those considered in this article. In certain cases, the Tribunal has adhered to the principle of independence and in other cases has completely ignored this principle - as if such a principle did not exist in banking or international law - without presenting sufficient reasons for ignoring this principle or justifying this principle in light of the fraud or manifest abuse. The only jurisdiction the Tribunal believed to possess was with regard to hearing bank guarantee cases that involved counter claim of original contract- this conclusion was reached in Case A-16. In its decision issued for Case A-16 regarding the transfer and integration of banking claims into the main contract claims, the Tribunal rendered itself ineligible to hear part of bank guarantee claims, and this is one of the faults associated with the Tribunal's decision in this case. Our investigation into the Tribunal jurisdiction in A-16 Case convinced us that - as compared with those set forth by the Islamic Republic of Iran - the arguments set forth by the United States were based on sounder foundations [16].

In this matter, author believe that the government of Islamic Republic of Iran whilst signing Algeria declarations, which only was edited in English, was not paying enough attention to the text of the contract and it does not have a strong legal team to interpretthe Algeria Declarations and the government of United States cleverly did not record the tribunal's jurisdiction to deal with bank guarantees in the Algeria Declarations and only knew the authority in the form of counterclaim lawsuit, however the violation of the tribunal from the principle of the independency of bank guarantees because that its jurisdiction is not mentioned in the declarations is not justified, because based on the principle of the independency that is known as the main principle, the objections of original contract does not affect the bank's commitment [17].

Considering to the raised issues, our response to the above question (whether the tribunal has been able to eliminate the legal ambiguities and promote the legal position of these tools through such judgments?) is negative.

Outside the Tribunal, numerous efforts towards recognizing the principle of independence of bank guarantees on the part of the International Chamber of Commerce, the United Nations Commission on International Trade Law (UNCITRAL), and banking committees in different countries who are considered important actors in international trade, demonstrates the significance of this principle in trade transactions as well as the necessity of taking a unified approach by all those involved in encountering the legal problems resulting from this principle. In line with this, the International Chamber of Commerce published set of rules entitled 'Uniform Rules for Demand Guarantees 458' in 1992. In our opinion, with due regard of the investigation conducted on the cases I have included in this article, the Tribunal could have, at the time, to establish for itself a strong position alongside other international institutions - particularly the International Chamber of Commerce - by setting forth a specific procedure for demand guarantees as well as emphasizing on the principle of independence of bank guarantees. However, unfortunately, the Tribunal missed this unique opportunity to develop and define this legal field. Both the Tribunal and the parties to the Algeria Declarations could have - in accordance with Clause 17 of the General Declaration regarding the resolution of disputes or interpretation or execution of each condition set forth in the Declaration established a separate special jurisdiction apart from that set forth in Clause 1, Article 2 of the Claims Settlement Declaration for resolving all the legal claims brought by Iranian banks regarding the letter of credit issued by American banks and financial institutions, thus preventing the non-recognition of the principle of independence. However, this was impossible at the time, and it is my belief that the Tribunal was unable to release itself from the non-legal considerations it was inevitably involved in at the time.

It is noteworthy that, as the first experience of its kind in dealing with independent bank guarantees, Rules 458 has in time been subjected to certain amendments and modifications regarding its execution and enforcement, and that the rules enforced in July 2010 were actually the latest version of the Uniform Rules for Demand Guarantees (URDG 758) which presented a comprehensive and efficient text to bankers and traders within an exact, transparent, and flexible framework covering the unique instrument of risk coverage. The International chamber of Commerce annually holds various international conferences on bank guarantees. So far, eleven such conferences have been held, the latest of which in Australia on 6 and 7 June 2016.

At its General Assembly meeting on 5 July 2011, the United Nations Commission on International Trade Law endorsed URDG 758. On 14 March 2012, the International Federation of Consulting Engineers upgraded the model guarantee forms used in connection with its model construction contracts to include the new URDG 758. The World Bank likewise announced on 26 June 2012 that it has updated its Procurement Division's model guarantee forms so they are now subject to URDG 758 in place of URDG 458. Other multilateral development banks follow these rules. Bank regulators, including Central Bank of Iran, and lawmakers, including the Organization for the Harmonization of Business Law in Africa (OHADA), approved URDG 758 and used them as model for national statutes now in force in 16 countries. 
The above leads us to the conclusion that bank guarantees play a significant role in the flourishing of international trade. International organizations - the International Chamber of Commerce in particular - have succeeded, through setting forth comprehensive and efficient regulations, in neutralizing the negative effects of the judgment issued by the Iran-United States Claims Tribunal (IUSCT) regarding non-recognition of the Principle of Independence.

\section{CONFLICT OF INTERESTS}

\section{There are no conflicts of interest.}

\section{References}

[1] Masoudi, A.R. 'Bank guarantees in Iran's Law and International Trade' Tehran, Danesh publications, Second edition, pp. 71 and 72.250,1 ${ }^{\text {st }}$ Vol. pp. $493-494,2$ nd Vol; 2012.

[2] Uniform Rules for Demand Guarantees ICC publication No. 458.

[3] Uniform Rules for Demand Guarantees ICC publication No. 758.

[4] The International Standby Practices (ISP98).

[5] Bertrams R.I. V.F.; "Bank Guarantees in International Trade", Kluwer law International, the Netherlands, second ed. p161; 1996.

[6] Shahbazinia, M., Tafreshi, M.E. 'The independency of Bank guarantees and its effects on international trade law', Journal of a Mofid, No. 37.p20; 2003.

[7] Mohebi, Mohsen. 'Bank guarantees in the procedures of Iran-US Claims Tribunal', Tehran, Law journal of International Legal affairs, No. 20.pp. 89-141; 1999.

[8] Marousi, A. 'Iran-U.S. Claims Tribunal reports', Tehran: President, Vice president of develop, refine and promulgating laws and regulations, the first volume. p. 79; 2011.

[9] Marousi, A. 'Iran-U.S. Claims Tribunal reports', Tehran: President, Vice president of develop, refine and promulgating laws and regulations, the second volume, p. 485; 2012.

[10] Retaining 1.418 billion US dollars in a special escrow account for the purpose of paying the original unpaid amount as well as the interest of the loans and credits referred to in Clause A above amounting to 3.667 billion US dollars (upon considering the due consumptions) and payment of other unpaid debts - either owed to American banking institutions or guaranteed by the Iranian government and its subsidiary organizations, institutions, and departments - and for the purpose of paying the disputed amounts regarding deposits, assets, and the interest (if any) of Iranian assets deposited in US banking institutions ....).

[11] Iran believed that parties in Algeria Declarations attached a special condition for bank claims and Commitment Documents is special agreement that describe such these bank claims and anticipate a special mechanism for settlement and payment.

[12] Marousi, A. 'Iran-U.S. Claims Tribunal reports', Tehran: President, Vice president of develop, refine and promulgating laws and regulations, the fourth Vol. p. 33;2013.

[13] Harza Engineering Company against Islamic Republic of Iran, Verdict No. 2-98-19 dated on December 30; 1982.

[14] International Technical Products against Islamic Republic of Iran, Verdict No. 3-302-186 dated on August $19 ; 1985$.

[15] Marousi, A. 'Iran-U.S. Claims Tribunal reports' Tehran: President, Vice president of develop, refine and promulgating laws and regulations, the eighth Vol, pp 65- 521; 2014.

[16] The case of Eastman Kodak Company, Verdict No. 3-227.12384-329, dated on January 22; 1987

[17] The case of Sylvania Technical Systems Incorporated, Verdict No 1-60-182 dated on June 27; 1980. 


\section{استقلال الضمانات المصرفية في الاعاوى القضائية الإيرانية الأمريكية: في البحث عن الطريقة القانونية لتقليل مخاطر العقود الاقتصادية \\ علي احمدي' \\ 'الباحث في قانون الدولية \\ محمد صادقي' \\ 'هرمز، جامعة هرمزكان-ايران}

الخلاصة

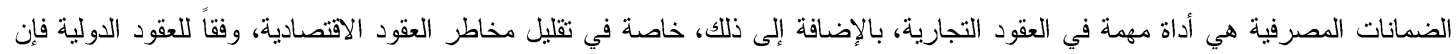
الضمان المصرفي له تأثير إيجابي على الموثوقية القانونية العقود الدولية بين الأطراف. وتمشيا مع ذلك، فإن استقلالية الضمان المصرفي من شروط العقد هي العي

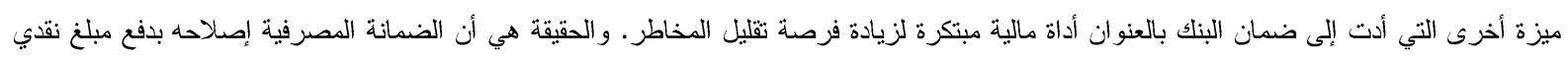

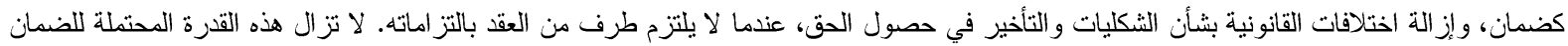

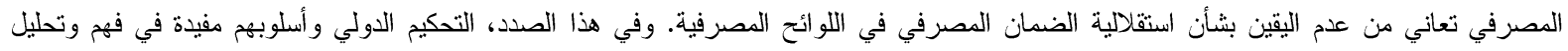

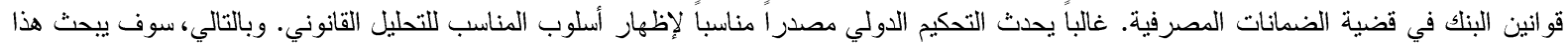

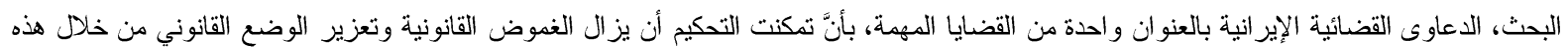

الأحكام?

الكلمات الالة: الضمانات المصرفية، استقلال الضمانات، الدعاوى القضائية الإيرانية الأمريكية. 